\title{
LUMBAR POSTURAL SYNDROME; EFFECTIVENESS OF PIRIFORMIS STRETCHING WITH HIP ROTATION sahreenanwar@yahoo.com
}

1. PPDPT (Riphah International University) BSPT (King Edward Medical University)

Senior lecturer RCRS (Riphah International University Faisalabad)

2. PPDPT (Riphah International University) BSPT (King Edward Medical University) Assistant professor RCRS (Riphah International University)

3. MS (OMPT)*(RIU)PPDPT (Riphah International university) BSPT (King Edward Medical University) Lecturer /Incharge physical therapy department Lyalpur campus Sargodha university

Consultant physiotherapist.(Chinoit General Hospital Faisaabad)

Correspondence Address: Sahreen Anwar

MS (OMPT)* RIU)PPDPT

(Riphah International University)

BSPT (King Edward Medical

University)

Lecturer /Incharge physical therapy department

Lyalpur campus Sargodha University Consultant physiotherapist

(Chinoit General Hospital Faisaabad)/ sahreenanwar@yahoo.com

Article received on:

20/02/2016

Accepted for publication:

01/08/2016

Received after proof reading:

07/10/2016

\section{Dr. Sameha Irshad', Dr. Arshad Nawaz Malik², Dr. Sahreen Anwar ${ }^{3}$}

ABSTRACT... Background: The most prevalent disabling condition in clinical practice is low back pain. The poor posture has highest risk for the development of low back pain in young population. There is different conservative treatment approaches used to treat lumbar postural syndrome. Purpose of The Study: The objective was to determine the effectiveness of Piriformis stretching with hip external rotation in the treatment of lumbar postural syndrome. Study Design: Randomized control. Setting: District Headquarter hospital Faisalabad. Period: 06 month from $01^{\text {st }}$ January- $30^{\text {th }}$ June 2014. Materials and Methods: The purposive sampling technique was used to collect sample of 30 patients and then assigned to 2 groups randomly (Hip external rotation HER and Hip Internal rotation HIR group). Standardized treatment protocol include heating modality, hamstring stretching, back strengthening \& stretching exercises and postural education was implemented to all patients. Participants in the hip external rotation (HER) group received Piriformis stretch with hip external rotation and participants in Hip Internal rotation (HIR) group received piriformis stretch with hip internal rotation as an additional treatment in order to compare both stretch positions. The changes in the symptoms were measured in the form of pain and Modified Oswestry Disability Index (MODI). Results: The statistical analysis showed the $P$ value for total score of Modified Oswestry Disability Index (MODI) was $(0.00<0.05)$. So there is a significant difference in both group showing that the piriformis stretching with hip external rotation is effective than hip internal rotation combined with conventional physical therapy in subjects with lumbar postural syndrome. Conclusions: It is concluded that piriformis stretching with hip external rotation together with conventional treatment is an effective treatment approach in treating lumbar postural syndrome.

Key words: Lumbar Postural Syndrome, Piriformis Stretching, Modified Oswestry Disability Index

Article Citation: Irshad S, Malik AN, Anwar S Lumbar postural syndrome; Effectiveness of piriformis stretching with hip rotation. Professional Med J 2016;23(10):12321236. DOI: $10.17957 / T P M J / 16.2971$

\section{INTRODUCTION}

The low backache is the most prevalent in the population and this is one of the high cost disability and gradually increasing in the developed nations. ${ }^{1}$ Low back pain (LBP) is usually associated with a change in the mobility of the LS and hip and leading to disability. ${ }^{2,3}$ In $70 \%$ of cases, low back pain has no obvious etiology or pathogenesis. ${ }^{4}$ It has been observed that most cases of LBP are non-specific, but a specific cause is identified in about $10 \%$ of cases. Evidence showed that most back pain is actually muscular or ligamentous in origin rather than skeletal. ${ }^{4}$

The $80 \%$ population experiences the low back pain episode once in life. ${ }^{6}$ Lifetime prevalence of LBP is $60-85 \% .^{7}$ The gradually increase in prevalence directly raise the economic burden on society and indirectly there is loss of work and other related costs. ${ }^{8}$ Numerous office workers and students spend their time in sitting posture, and then relax in the evening with same poor posture which leads to the development of imbalance in the activity of musculature. ${ }^{9}$

There are different condition related with pathology of low back pain, the postural syndrome mostly occur in young population and it is frequent in those who have poor posture during their activities. ${ }^{10}$ The stress on the muscles and other soft tissue determines the efficacy 
and performance of musculature, the poor imbalance posture lead to the development of some pathological conditions. The literature revealed that among many other factor most predominant factors for low back pain is poor posture. The most important variables that have an effect on an individual are related to sustained postures. ${ }^{9}$ There are number of studies that have documented a strong link between sustained flexed postures and back pain in populations with or without existing back pain. ${ }^{11-16}$

There are few deep muscles around lower lumbar region which always protect the uneven load on lumbar and maintain the core stability. The Piriformis is one of important deep muscles which is prone to get tightness in pathological conditions of low back region. There is multiple way to diagnose the involvement of Piriformis muscle in literature. Hallin suggested that buttock pain is usually due to piriformis pathology that was exacerbated by sitting and no other symptoms. ${ }^{17}$ Beatty described that when affected flexed hip is in forced adduction with the patient lying on the painful side, lower lumbar pain is produced as a diagnostic criterion of piriformis syndrome. The hip in flexion and few degree adductions with internally rotation, a position commonly FAIR position (Flexion, Adduction, and Internal Rotation) is important to diagnose the Piriformis muscle syndrome. ${ }^{17}$

The function of Piriformis is always crucial to explain and understand, the same muscle is external rotator in hip extension while internal rotator in hip flexion more than 60 degree. ${ }^{18}$ The external rotation is considered the most important function of those muscles among all other functions. ${ }^{19}$ Function of the piriformis is External Rotation of the femur during hip ext, ABD during hip flex and Internal Rotation during hip flexion is recently considered the important not for diagnosis but for treatment. ${ }^{20}$ The specific designed stretching techniques are effective to improve the function and manage pain in piriformis syndrome. ${ }^{23}$ The stretching enhances the elasticity and length of muscle to improve the ranges around the joint. ${ }^{24}$
There are different types of Piriformis stretches. It is crucial to find specific and effective stretch of piriformis muscle to gain maximum therapeutic effects. A very little evidence is present about the optimal piriformis stretching. There is lack of consensus regarding stretch position. There is little research regarding sequencing of stretch components. In clinical practice, piriformis stretches are chosen on the basis of clinical expertise rather than evidence-based practice. ${ }^{19}$ There is need to identify the best stretching methods for Piriformis to provide quality care and cost effective management to patients. ${ }^{23}$ The main focus of the study is to find out effectiveness of specific piriformis stretching in lumbar postural syndrome, to find out the position which optimally stretches piriformis and to determine improvement in functional status by specific piriformis stretching.

\section{MATERIAL AND METHODS}

The study design was a randomized control trial and conducted from $01^{\text {st }}$ January- $30^{\text {th }}$ June 2014. The purposive sampling technique was used to collect sample of 30 patients and then assigned to 2 groups randomly (Hip external rotation HER and Hip Internal rotation HIR group). The data was collected from District Headquarter hospital Faisalabad and the inclusion criteria was patient aged from 20-60 years and with postural impairments and the radiculopathy, inflammatory disease, disc lesion and hip pathology was excluded. All the participants with lumbar postural syndrome that reported to physiotherapy Departments were screened after finding their suitability as per the inclusion and exclusion criteria, they were requested to participate in the study. Before recruiting a written informed consent was taken from the patients and described the detail of management. The HER group received back strengthening and stretching exercises, hamstring stretching, heating modality, postural education followed by piriformis stretching with hip external rotation with 10-15 repetition and 15 sec hold for each on alternate days for 15 days. The HIR group received all treatment followed by piriformis stretching with hip internal rotation with 10-15 repetition and $15 \mathrm{sec}$ hold for each on alternate days for 15 days. The measurements 
were taken in the form of Modified Oswestery Disability Index (MODI). The Hypothesis was "Piriformis stretch with hip external rotation is more effective than hip internal rotation stretch.

\section{RESULTS}

The sample were composed of 34 patients and mean age was $31-40$ years.
The $p$ value of pain intensity is $(P<0.05)$ so there is a significant difference in both groups.

The $P$ value of total MODI score is $(P<0.05)$ so there is a significant difference in both groups. Hence it is stated that "Piriformis stretch with hip external rotation is more effective than hip internal rotation stretch".

\begin{tabular}{|c|c|c|}
\hline Variable & Mean $\pm S D(n=30)$ & $P$ value \\
\hline $\begin{array}{l}\text { Pain Intensity } \\
\text { Interventional Group }(n=15) \\
\text { Control Group }(n=15)\end{array}$ & $\begin{array}{l}1.05 \pm 0.82 \\
1.70 \pm 1.21\end{array}$ & 0.002 \\
\hline $\begin{array}{l}\text { MODI Modified Oswestery Disability Index (Total Score) } \\
\text { Interventional Group }(n=15) \\
\text { Control Group }(n=15)\end{array}$ & $\begin{array}{l}1.23 \pm 0.43 \\
2.05 \pm 0.65\end{array}$ & 0.003 \\
\hline $\begin{array}{l}\text { Post-Social Life } \\
\text { Interventional Group }(n=15) \\
\text { Control Group }(n=15)\end{array}$ & $\begin{array}{l}1.0588 \pm .82694 \\
1.7059 \pm .58787\end{array}$ & 0.013 \\
\hline $\begin{array}{l}\text { Post travelling } \\
\text { Interventional Group }(n=15) \\
\text { Control Group }(n=15)\end{array}$ & $\begin{array}{l}1.0000 \pm .61237 \\
1.6471 \pm .60634\end{array}$ & 0.004 \\
\hline
\end{tabular}

There was significant difference regarding the different activities in both interventional and control groups. The $(P<0.05)$ was in personal care, walking, sitting, standing and employment. There was no significant effect on some component of inventory and the $(P>0.05)$ in social life, travelling and sleeping, which explains that there is no change in these activities by alteration of the type of stretch.

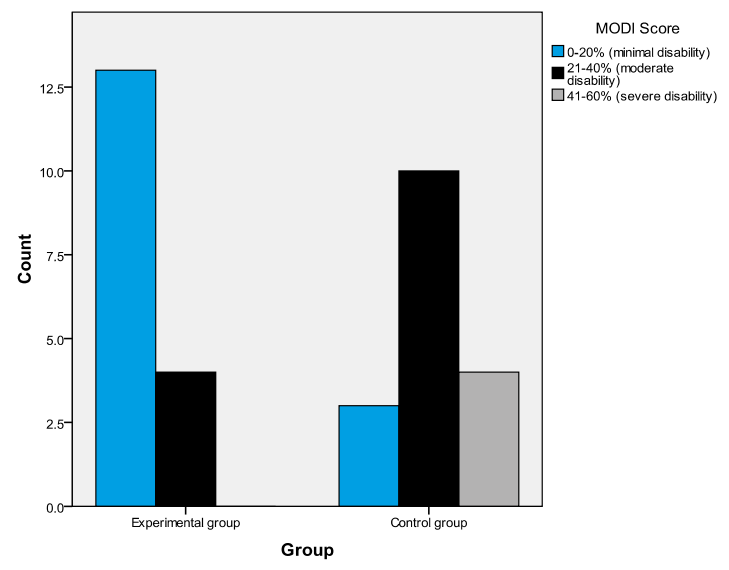

CLUSTER BAR CHART

\section{DISCUSSION}

Piriformis stretching plays crucial impact for the relief of pain and other symptoms in lowe backache. There are different types of Piriformis stretches. It is crucial to find specific and effective stretch of piriformis muscle to gain maximum therapeutic effects.

The specificity and effectiveness of type of stretching is very important to find out. A very little evidence is present about the optimal piriformis stretching. There is lack of consensus regarding stretch position. There is little research regarding sequencing of stretch components. In clinical practice, piriformis stretches are chosen on the basis of clinical expertise rather than evidencebased practice. A study pilot conducted in 2006 to assess the Piriformis stretching efficacy through pelvic fluoroscopy. In this study different position of Piriformis were compared and the change in the anatomical length was measured through fluoroscopy. The summary of the findings of the study showed greatest stretch in upper sacral fibers with $90^{\circ}$ Hip Flexion and $50^{\circ}$ External Rotation and least separation at both upper and 
lower sacral fibers with $90^{\circ}$ Hip Flexion and $40^{\circ}$ Internal Rotation. The results are correlated with this study about the effectiveness of external rotation in Piriformis stretch. ${ }^{23}$ The study showed the importance of sequence of external rotation with combination of other movements, a study showed the detail description of sequence through CT scan findings. The summary of the findings showed that both stretch positions $\left(90^{\circ}\right.$ hip Flex, ADD, ER) and ( $90^{\circ}$ hip Flex, ER, ADD) resulted in an increase in piriformis length from supine and Stretch ADD from supine showed statistical significance while stretch ER from supine was not significant. ${ }^{19}$ Taking into account the literature review different researcher explored different aspects of the treatment techniques. More were aimed towards the general stretching of back muscles in lumbar postural syndrome. Some studies regarding the treatment aspects of the specific stretching technique were focused specifically to piriformis syndrome. ${ }^{24}$

\section{CONCLUSIONS AND RECOMMENDATIONS}

The results suggest that the addition of specific piriformis stretch to a multimodal treatment program of generalized strengthening and stretching exercise yields significant additional benefit to pain, function, or disability in patients with lumbar postural syndrome. On the basis of the findings in the research work, the piriformis stretch with hip external rotation is an effective treatment in lumbar postural syndrome.

It is recommended that conservative management incorporating piriformis stretching with hip rotation and postural education can be effective in addressing musculoskeletal presentations of low back pain Copyright@ 01 Aug, 2016.

\section{REFERENCES}

1. Koes B, Van Tulder M, Thomas S. Diagnosis and treatment of low back pain. BMJ: British Medical Journal. 2006; 332(7555):1430.

2. Shum GL, Crosbie J, Lee RY. Effect of low back pain on the kinematics and joint coordination of the lumbar spine and hip during sit-to-stand and stand-to-sit. Spine. 2005; 30(17):1998-2004.
3. Hayden J, Van Tulder M, Malmivaara A, Koes B. Exercise therapy for treatment of non-specific low back pain. Cochrane Database Syst Rev. 2005; 3(3).

4. Borenstein DG, Calin A. Fast Facts: Low Back Pain: Health Press; 2012.

5. Bridger R. Introduction to ergonomics: CRC Press; 2003.

6. Freburger JK, Holmes GM, Agans RP, Jackman AM, Darter JD, Wallace AS, et al. The rising prevalence of chronic low back pain. Archives of Internal Medicine. 2009; 169(3):251.

7. Malik AN, ur Rasul HN, Siddiqi FA. Cross sectional survey of prevalence of low back pain in forward bend sitting posture. Rawal Medical Journal. 2013;38(3):253-5.

8. Krismer M, Van Tulder M. Low back pain (non-specific). Best Practice \& Research Clinical Rheumatology. 2007; $21(1): 77-91$.

9. May S, Lomas D. Posture, the lumbar spine and back pain.

10. Ghazal J, Malik AN, Sultana B, Minhas A. Daily travelling and low back pain in University Students. Rawal Medical Journal. 2014;39(1):25-7.

11. Bakker EW, Verhagen AP, Lucas $C$, Koning HJ, de Haan RJ, Koes BW. Daily spinal mechanical loading as a risk factor for acute non-specific low back pain: a case-control study using the 24-Hour Schedule. European Spine Journal. 2007; 16(1):107-13.

12. Huygens MW. Class break exercises to reduce visual discomfort and musculoskeletal pain in primary school children.

13. O'Sullivan K, O'Keeffe M, O'Sullivan L, O'Sullivan P, Dankaerts $W$. The effect of dynamic sitting on the prevention and management of low back pain and low back discomfort: a systematic review. Ergonomics. 2012; 55(8):898-908.

14. McGill SM, Fenwick CM. Using a pneumatic support to correct sitting posture for prolonged periods: a study using airline seats. Ergonomics. 2009; 52(9):1162-8.

15. Geldhof E, De Clercq D, De Bourdeaudhuij I, Cardon G. Classroom postures of 8-12 year old children. Ergonomics. 2007; 50(10):1571-81.

16. Womersley L, May S. Sitting posture of subjects with postural backache. Journal of manipulative and physiological therapeutics. 2006; 29(3):213-8. 
17. Broadhurst NA, Simmons DN, Bond MJ. Piriformis syndrome: correlation of muscle morphology with symptoms and signs. Archives of physical medicine and rehabilitation. 2004; 85(12):2036-9.

18. Byrd J. Piriformis syndrome. Operative Techniques in Sports Medicine. 2005; 13(1):71-9.

19. Andrews J, Wells H. Background Information.

20. Cassidy L, Walters A, Bubb K, Shoja MM, Tubbs RS, Loukas M. Piriformis syndrome: implications of anatomical variations, diagnostic techniques, and treatment options. Surgical and radiologic anatomy. 2012; 34(6):479-86.
21. Postural Syndrome [cited 2013 10th Dec]; Available from: http://www.physioadvisor.com.au/8390250/ postural-syndrome-posture-pain-poor-posture-.htm.

22. Burns E. Getting Well Naturally Newsletter. Tucson, AZ. 2001; 31(3).

23. Güvençer M, Akyer P, lyem C, Tetik S, Naderi S. Anatomic considerations and the relationship between the piriformis muscle and the sciatic nerve. Surgical and radiologic anatomy. 2008; 30(6):467-74.

24. Byrd J. Piriformis syndrome. Operative Techniques in Sports Medicine. 2005;13(1):71-9.

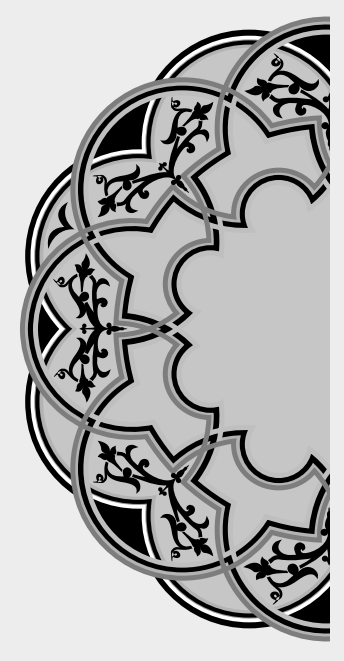

\section{"The richest man is not he who has the most, but the who needs the least."}

Unknown

\section{AUTHORSHIP AND CONTRIBUTION DECLARATION}

\begin{tabular}{|c|l|l|l|}
\hline Sr. \# & \multicolumn{1}{|c|}{ Author-s Full Name } & \multicolumn{1}{|c|}{ Contribution to the paper } & Author=s Signature \\
\hline 1 & Dr. Sameha Irshad & $\begin{array}{l}\text { Data collection / } \\
\text { Introduction Procedure }\end{array}$ \\
\hline 2 & Dr. Arshad Nawaz Malik & $\begin{array}{l}\text { Study design/Statistical } \\
\text { analysis } \\
\text { Result/Conclusion/ Article } \\
\text { writing }\end{array}$ \\
\hline 3 & Dr. Sahreen Anwar & \begin{tabular}{l} 
wring \\
\hline
\end{tabular}
\end{tabular}

